\title{
The Relationship between Healthy and Clean Life Behavior and Hepatitis A Incidence in Children of Rural Areas
}

\author{
Authors \\ Budi Pramono ${ }^{1}$, Joko Sulistiyo ${ }^{2}$, Andhani Windari ${ }^{3}$, Sudiyono $^{4}$, Salikun $^{5}$, \\ Asep Tata Gunawan' \\ ${ }^{1,2}$ Politeknik Kesehatan Kementrian Kesehatan Jakarta II , Indonesia \\ ${ }^{3,4,5,6}$ Politeknik Kesehatan Kementrian Kesehatan Semarang, Indonesia \\ Corresponding Author \\ Budi Pramono \\ Politeknik Kesehatan Kementrian Kesehatan Jakarta II, Indonesia
}

\begin{abstract}
Background: One of the infectious diseases that still become a priority in Indonesia is hepatitis A.

Objectives: This study aimed to obtain information on a relationship between a clean and healthy life behavior that is associated with the incidence of hepatitis A among patients visiting the Health Community Center or Pusat Kesehatan Masyarakat of Wanareja I Subdistrict of Cilacap, Central Java, Indonesia.

Methods: The study applied the case control with 98 samples consisting 49 people with Hepatitis A as cases and 49 healthy people as controls. The relationship among variables is tested with the Chi-Square test.

Results: The results of this study reveal a positive association between the behavior of clean and healthy life with the incidence of hepatitis A concerning the source of fresh water, the habit of washing hands after defecation, boiling drinking water, how to wash cutlery, sorting cutlery and practice of eating snacks outside.

Conclusions: Though the above factors are closely related to the incidence of hepatitis A, the respondents' attention to clean and healthy living habits are still low in the respective areas signaling that Health Community Center or Pusat Kesehatan Masyarakat should take more proactive efforts to provide information to the community in rural areas.
\end{abstract}

Keywords: Hepatitis A, clean and healthy, living behavior, rural areas.

\section{Introduction}

Health development aims to increase the awareness, willingness, and ability of healthy life for everyone to reach the optimal degree of public health. To implementation of development goals requires parties who care about the clean and healthy lifestyle as well as the surrounding environment. Health problems remains a priority in Indonesia are communicable diseases including Hepatitis A (Depkes RI, 2010).

Hepatitis A is an infectious disease caused the hepatitis A virus. The virus can attack various groups regardless of national borders as these viruses exist almost worldwide. 
As hand washing is rarely performed by students at the school, Hepatitis A is more common in school children and young adults (Kementerian Kesehatan RI, 2014).

Indonesia includes endemic areas of Hepatitis A. Based on data from hospitals in Indonesia, hepatitis $\mathrm{A}$ is the most significant part of the cases with the one with acute categories were hospitalized ranging between 39.8 to $68.3 \%$, and sadly the outbreaks of hepatitis A is usually repeated every year including in the rural areas of Cilacap District, Central Java province. The last five years was found 119 cases of hepatitis A in sub-district Wanareja and the District Dayeuhluhur (Dinas Kesehatan Kabupaten Cilacap, 2013).

Based on the above background it is possible the outbreak of hepatitis A may strike again in this area. Transmission of hepatitis is very fast because the transfer is straightforward mainly among people who pay less attention to the factors of transmission. These factors include lack of proper hygiene practices such as washing hands before eating, rinsing hands with soap after defecation, poor environmental sanitation.

\section{Materials and Methods}

This research is an observational approach, casecontrol to obtain information about the factors of clean and healthy life behavior that affect the incidence of hepatitis A.

A sample of cases are total of 49 people suffering from hepatitis A recorded at the health center of Wanareja I in Cilacap District Central Java Province and the control sample are 49 people of the healthy family of each family or the closest neighbors who have similar characteristics (age, gender, location).

Data collected are tabulated and analyzed descriptively with the frequency distribution table with an explanation, as well as bivariate analysis was conducted to see the relationship between the dependent variable (incidence of hepatitis A ) and independent variables (washing hands after defecation, boiling drinking water, washing cutlery, sorting cutlery, eating snacks outside ) by employing Chi-square test .

\section{Results}

The relationship between healthy and clean life behavior and the incidence of hepatitis $\mathrm{A}$ in Puskesmas I Wanareja Cilacap district is presented in the following tables.

Table 1 Cross tabulation between with habit of washing hands after defecation the incidence of Hepatitis A

\begin{tabular}{|l|c|c|c|c|}
\hline Washing hands after defecation & Case & & Control & \\
\hline No & $\mathbf{n}$ & $\mathbf{\%}$ & $\mathbf{n}$ & $\mathbf{\%}$ \\
\hline Yes & 36 & $73.5 \%$ & 22 & $44.9 \%$ \\
\hline Total & 13 & $26.5 \%$ & 27 & $55.1 \%$ \\
\hline Chi Square $=7.139$ & 49 & $100 \%$ & 49 & $100 \%$ \\
\hline
\end{tabular}

Table 1 shows that the habit of not washing hands after using the toilet is more abundant in case

group of $73.5 \%$ compared to the control group of $44.9 \%$.

Table 2. Cross-tabulation of boiling drinking water with the incidence of Hepatitis A

\begin{tabular}{|c|c|c|c|c|}
\hline $\begin{array}{l}\text { How to Boil Water (after boiling allowed to } \\
\text { stand for 2-5 minutes) }\end{array}$ & Cases & & Controls & \\
\hline & $\mathbf{n}$ & $\%$ & $\mathbf{n}$ & $\%$ \\
\hline Did not meet the requirements & 35 & $71.4 \%$ & 20 & $40.8 \%$ \\
\hline Compliance & 14 & $28.6 \%$ & 29 & $59.2 \%$ \\
\hline Total & 49 & $100 \%$ & 49 & $100 \%$ \\
\hline Chi Square $=8.122$ & $P$ value $=0.004$ & & $\mathrm{OR}=3.625$ & \\
\hline
\end{tabular}

Table 2 shows that boiling of drinking water does proportion is found in case group of $71.4 \%$ not meet the requirements in a more substantial compared to the control group of $40.8 \%$. 
Table 3 Cross-tabulation of washing cutlery with the incidence of Hepatitis A

\begin{tabular}{|l|c|c|c|c|}
\hline How to wash cutlery & Cases & & Controls & \\
\hline & $\mathbf{n}$ & $\mathbf{\%}$ & $\mathbf{n}$ & $\mathbf{\%}$ \\
\hline Do not use running water & 42 & $85.7 \%$ & 24 & $49.0 \%$ \\
\hline Using drinking water & 7 & $14.3 \%$ & 25 & $51.0 \%$ \\
\hline Total & 49 & $100 \%$ & 49 & $100 \%$ \\
\hline Chi-Square $=13.410$ & P value $=0.000$ & & OR= 6.250 & \\
\hline
\end{tabular}

Table 3 shows that how to wash cutlery not to use $85.7 \%$ compared to the control group of $49.0 \%$. running water is greater in the case group of

Table 4 Cross-tabulation of with the incidence of Hepatitis A

\begin{tabular}{|l|c|c|c|c|}
\hline Sorting cutlery & Cases & & Control & \\
\hline & $\mathbf{n}$ & $\boldsymbol{\%}$ & $\mathbf{n}$ & $\boldsymbol{\%}$ \\
\hline Yes & 33 & $67.3 \%$ & 23 & $6.9 \%$ \\
\hline No & 16 & $32.7 \%$ & 26 & $3.1 \%$ \\
\hline Total & 49 & $100 \%$ & 49 & $00 \%$ \\
\hline Chi Square $=3.375$ & P value $=0.001$ & & OR: 2.332 & \\
\hline
\end{tabular}

Table 4 shows that sorting cutlery is in case group of $67.3 \%$ compared to the control group of $46.9 \%$.

Table 5 Cross-tabulation habit of eating snacks outside with the incidence of hepatitis A

\begin{tabular}{|l|c|c|c|c|}
\hline Habits of eating out & Cases & & Control & \\
\hline & $\mathbf{n}$ & $\boldsymbol{\%}$ & $\mathbf{n}$ & $\boldsymbol{\%}$ \\
\hline Yes & 41 & $83.7 \%$ & 22 & $44.9 \%$ \\
\hline No & 8 & $16.3 \%$ & 27 & $55.1 \%$ \\
\hline Total & 49 & $100 \%$ & 49 & $100 \%$ \\
\hline Chi Square $=14.400$ & P value $=0.000$ & & OR: 6.290 & \\
\hline
\end{tabular}

Table 5 shows that habit of eating snacks outside in a more substantial proportion is found in case group of $83.7 \%$ compared to of $44.9 \%$ in control group.

\section{Discussion}

The relationship between hand washing with soap after defecation with the incidence of Hepatitis A shows the value of Chi-Square $=7.139$ with a $\mathrm{P}$ value 0.004 less than $\alpha=0.05$ indicating there is a significant relationship between hand washing after defecation with the incidence of hepatitis A. Odd ratio shows the amount of 3.399 means that respondents are not used washing hands after defecation, the risk of Hepatitis A can be transmitted is 3.399 (rounded to 3) times greater than the respondents washing hands after defecation.

This is consistent with (Maryunani, 2013) where Hepatitis A patients should maintain personal hygiene when defecating on the toilet and flush it thoroughly so that the stool (faeces) runs into the hole of the bathroom and wash hands after using the toilet using soap with water flow so that their hands are spotless from Hepatitis A virus.

The relationship of boiling drinking water with the incidence of Hepatitis A shows the value of Chi-Square $=8.122$ with a $\mathrm{P}$ - value $=0.002$ indicating a significant correlation between boiling drinking water (left after 2-5 minutes) and the incidence of hepatitis A. Odd ratio shows a value of 3.625 means that respondents boiling drinking water does not meet the requirements, the risk of being infected by Hepatitis $A$ is 3.625 (rounded to 4) times greater than the respondents boiling the drinking water to meet the criteria. Drinking water is a requirement that must be fulfilled in the human body, but if consumed drinking water has been contaminated by viruses and bacteria from handlers or in boiling water has not met the requirements will make those who drink become sick. This is consistent with the theory (Cahyono, 2009) where environmental sanitation on the sources of clean water does not 
meet the requirements and be a factor affecting the incidence of hepatitis A.

The relationship between washing cutlery with the incidence of Hepatitis A shows the value of ChiSquare $=13.410$ with amount $\mathrm{P}$-value $=0.001$ proving the relationship between food equipment washing with the prevalence of hepatitis A. Odd ratio shows the importance of 6.250 meaning that respondents who do not wash tableware by using running water can be infected with hepatitis A 6.250 (rounded to 6) times greater than the respondents by washing tableware using flowing water.

The relationship between cutlery sorting with the incidence of Hepatitis A shows the value of Chi-Square $=3.375$ and $\mathrm{P}$-value 0.041 indicating there is a significant relationship between cutlery sorting with the prevalence of hepatitis A. Further, odd ratio shows that the value of 2.332 meaning that respondents who have mixed feeding equipment can be risky of being infected with Hepatitis A with is 2,332 (rounded into 2) times greater than the respondents whose cutlery unmixed.

This is by (Cahyono, 2009) stating that equipment of food not separated (in the family) when there is one family member suffering from Hepatitis A, it can infect other family members using the same equipment.

The calculation result on habit of eating snacks outside relationship with the incidence of Hepatitis A shows the value of Chi-Square = 14.400 with $\mathrm{P}$-value 0.000 indicating there is a significant relationship between the buying habits of eating snacks outside with Hepatitis A. Besides, odd ratio shows the value of 6.290 meaning that respondents often buy snacks out, the risk of contracting Hepatitis A is 6.290 (rounded to 6) times greater than the respondents who do not purchase meal outside.

The unhygienic food serving outside is often a significant factor in the transmission of Hepatitis A.

This is consistent with (Marynunani, 2013) that buying food (snacks) outside can be a source of transmission of Hepatitis A as the sellers suffering from Hepatitis A (ill) did not wash hands before preparing food. Behavior like this could contaminate the food. Solutions that can be done is by not too often to purchase the snack outside or packing the lunch from home that has been cooked by the mother. However, if wishing to buy meal outside the area, the hygiene, health of food handlers and food conditions to be purchased must be observed.

\section{Conclusions}

The results of the study on the relationship between the physical environment of the house with the incidence of hepatitis A in children under five in Puskesmas I Wanareja are summed up as follows.

1. There is a relationship between the habit of not washing hands after defecation with the incidence of hepatitis A ( $\mathrm{p}=0.004$; OR $=3.399$ ).

2. There is a relationship between How to boil drinking water with the incidence of hepatitis $\mathrm{A}(\mathrm{p}=0.002$; OR $=3.625)$.

3. There is a relationship between How to wash utensils that do not use running water to the incidence of hepatitis A $(\mathrm{p}=0.000$; OR $=6.250$ ).

4. There is relationship between the proportion of mixed feeding equipment with the incidence of hepatitis, $(\mathrm{p}=0.001$; OR $=$ 2.332)

5. There is a relationship between the habit of eating snacks outside with the prevalence of hepatitis A ( $\mathrm{p}=0.000$; OR $=6.290)$.

\section{References}

1. Cahyono, Suharjo, 2009. Hepatitis A, Yogyakarta:Kansius

2. Depkes RI, 2010. Laporan Hasil Riset Kesehatan Dasar Indonesia 2007, Jakarta : Badan Penelitian Pengembangan Kesehatan.

3. Dinas Kesehatan Kabupaten Cilacap, 2013. Laporan KLB Hepatitis A Di Puskesmas I Wanareja dan Puskesmas 
Dayeuh Luhur Tahun 2013, Cilacap: Dinas Kesehatan Kabupaten Cilacap

4. Kementerian Kesehatan RI, 2014. Situasi dan Analisis Hepatitis. Jakarta : Pusat Data dan Informasi Kemenkes RI.

5. Maryunani, Anik, 2013. Perilaku Hidup Bersih dan Sehat, Jakarta: C.V Trans Info Media. 